\title{
Energia 2030 Agendan eta Garapen Iraunkorrerako Helburuetan: 7. GIHaren xede eta adierazleen analisia Euskal Autonomia Erkidegoan
}

(Energy within the 2030 Agenda and the Sustainable Development Goals: Analysis of objectives and monitoring indicators of the $7^{\text {th }}$ SDG in the case of the Autonomous Community of the Basque Country)

\author{
Unai Villena*1,2, Ortzi Akizu-Gardoki ${ }^{3,4,5}$ \\ ${ }^{1}$ Ingeniaritza Elektrikoa Saila, Bilboko Ingeniaritza Eskola (UPV/EHU) \\ ${ }^{2}$ Hegoa Nazioarteko Lankidetza eta Garapenari Buruzko Ikasketa Institutua (UPV/EHU) \\ ${ }^{3}$ Adierazpen Grafiko eta Ingeniaritza Proiektuak Saila, Bilboko Ingeniaritza Eskola \\ (UPV/EHU) \\ ${ }^{4}$ Ekopol: Transition Pathways Research Group (UPV/EHU) \\ ${ }^{5}$ Life Cycle Thinking Group (LCTG), Bilboko Ingeniaritza Eskola (UPV/EHU)
}

\begin{abstract}
LABURPENA: Artikulu honek Nazio Batuen 2030 Agendako Garapen Iraunkorrerako Helburuen (GIH) artean zazpigarrena aztertzen du: biztanle ororentzat energia garbia eskuragarri izatea. Helburu hori hainbat lurraldetan inplementatzeko eta haren jarraipena egiteko bideak aztertu dira, baita zenbait autoreren arabera dituen alde onak edo potentzialtasunak eta argi-ilunak ere. Azken urteotako literaturak GIHen jarraipenari buruz zer dioen berrikusi, eta, horren ostean, 7. GIHaren ezarpena makro eskalatik mikro mailara nolakoa izaten ari den aztertu da, Europatik hasita, Euskal Autonomia Erkidegoaren (EAE) kasu konkretua ardatz gisa hartuz. Horretarako, askotariko gobernu mailetan (besteak beste, Europar Batasuna, Espainiako estatuko gobernua, Eusko Jaurlaritza, foru-aldundiak eta udalak) 7. GIHa lortze aldera zehaztu diren xede eta adierazleak alderatu dira, baita haien aniztasuna erakutsi ere, eta 2017. urtera bitartean adierazle horiek izandako bilakaera aztertu da. Azterketatik ondorioztatu da Europa mailan helburuak estandarizatu diren arren helburuok estatu-mailan eta handik beherakoetan ez dutela adierazle nahikorik ezarririko xedeen jarraipen osatua egiteko. Hala, adierazleak estandarizatzen eta datu-iturriak hobetzen jarraitzeko beharra ikusi da, hots, agerian utzi da horrek konparaketak egiteko dakartzan zailtasunak.

HITZ GAKOAK: 2030 Agenda; Garapen Iraunkorrerako Helburuak; energia berriztagarriak; 7. GIHa; energia eskuragarria; energia jasangarria.

ABSTRACT: This article examines the 2030 Agenda's Sustainable Development Goal 7: affordable and clean energy for all. It has been analyzed the ways in which this goal is being implemented in different territories and how it is planned to be monitored, as well as its pros and cons, according to different authors. The literature of recent years about monitoring of SDGs has been compared, having as well a full look at how the implementation of the $7^{\text {th }}$ SDG has been planned from the macro scale to the micro level, starting from the European frame and having as scope the Basque Country. To this end, they have been compared the targets and indicators set by governments of different levels (including the European Union, the Spanish State Government, the Basque Government, the Basque Provincial Councils and City Councils) for achieving SDG 7, showing their diversity. The evolution of these indicators has been examined up to 2017, and finally, the findings made have been contrasted with the analyzed literature. It has been concluded that, although there is a standardization at the European level, there is a lack of indicators at state and provincial level to monitor the achievements in a comprehensive integral way. It has been detected the need to standardize indicators and improve data sources, revealing difficulties in making comparisons.
\end{abstract}

KEYWORDS: 2030 Agenda; Sustainable Development Goals; renewable energies; 7th SDG; affordable energy; sustainable energy.

* Harremanetan jartzeko / Corresponding author: Unai Villena, Euskal Herriko Unibertsitatea UPV/EHU, Ingeniaritza Elektrikoa Saila, Bilboko Ingeniaritza Eskola. Ingeniero Torres Quevedo Plaza (48013 Bilbao). - unai.villena@ehu.eus - https:// orcid.org/0000-0002-5458-9768.

Nola aipatu / How to cite: Hernáez Villena, Unai (2021). «Energia 2030 Agendan eta Garapen Iraunkorrerako Helburuetan: 7. GIHaren xede eta adierazleen analisia Euskal Autonomia Erkidegoan»; Ekaia, ale berezia 2021, 119-142. (https://doi.org/10.1387/ekaia.22093).

Jasotze-data: 2020, urriak 02; Onartze-data: 2021, urriak 18

ISSN 0214-9001 - elSSN 2444-3255 / (C) 2021 UPV/EHU

(i) (-) $\odot$ Lan hau Creative Commons Aitortu-EzKomertziala-LanEratorririkGabe 4.0 Nazioartekoa lizentzia baten mende dago 


\section{SARRERA}

\subsection{Energia nazioarteko agendan egotearen jatorria}

Nazioartean onartu da energia modu fidagarrian eskuragarri izatea funtsezkoa dela herrialdeen hazkunde ekonomikoa lortzeko, pertsonen ongizatea bermatzeko eta ingurumena zaintzeko [1]. Mundu osoko biztanleen osasuna bermatzeko ere ezinbestekotzat jo da gaur egungo COVID-19aren pandemiaren testuinguruan [2]. Hainbat herrialdetan giza garapena sustatzeko, Nazio Batuen Erakundeak guztiontzako energia iraunkorraren hamarkada izendatu zuen 2014-2024 aldia, hiru helburu nagusi adostuta: zerbitzu energetiko modernoetarako sarbidea bermatzea mundu osoan, efizientzia energetikoaren tasa globala bikoiztea eta energia berriztagarriak sustatzea [3]. Ildo beretik, 2030 Agendatik eratorritako Garapen Iraunkorrerako 17 Helburuetako 7.a energiari eskainia dago, eta «energia eskuragarria, fidagarria, jasangarria eta modernoa bermatzea guztiontzat» aldarrikatzen du [4].

2030 Agenda 2015. urtean jarri zen indarrean. Garapen Iraunkorrerako Helburuak (GIH) argitaratu, eta haiei lotutako 169 erronka eta 232 adierazle ezarri ziren, hamabost urteko epean betetzeko asmoarekin [5]. GIHak Nazio Batuen Erakundeak aurretik bultzatutako bi prozesu nagusik bat egitearen emaitza izan ziren: alde batetik, pobrezia desagerraraztea xede zuten Milurtekoko Garapen Helburuak (MGH), eta, bestetik, ingurumena babesteko eta garapen iraunkorraren aldeko «Rio+20» bidea [6]. Ondorioz, GIHak MGHen alde egindako lanean oinarritzen dira, baina lehentasun eta lan-eremu berriak txertatu dira (klima-aldaketa, kontsumo iraunkorra, bakea eta justizia, besteren artean), eta hiru ezaugarri nabarmendu: unibertsaltasuna, inor atzean ez uztearen printzipioa eta helburu guztien integraltasuna [7].

2030 Agendaren aurrekari izan ziren bi prozesuetan, energiaren trataera ezberdina izan zen. MGHetan energia esplizituki aipatzen ez bazen ere, helburuok indarrean jarri eta urte gutxira azaldu ziren energiaren eskuragarritasuna eta MGHen lorpenaren arteko harremana azpimarratzen zuten hainbat argitalpen, eta baita energiaren eta giza garapenaren arteko harremanaz zihardutenak ere. Hala, hainbat egile eta erakundek agerian utzi zuten MGHetan energiarekin lotutako helburu, erronka eta adierazlerik izan ez arren helburuok ezin beteko zirela kalitatezko energia-zerbitzuak eskuragarri egin eta energia-iturriak dibertsifikatu ezean $[8,9,10]$. «Rio+20» bidean, aldiz, energiak zeresana izan zuen hasieratik. Izan ere, Agenda 21 programaren ondorioz abiarazitako plan askok, zeinak 1992ko Lurraren Goi Bileraren ostean jarri baitziren martxan garapen iraunkorra sustatzeko, energia izan zuten beren lan-ildoen artean, eta energia izan zen «Nahi dugun etorkizuna» Nazio Batuen Garapen Iraunkorrari buruzko Rio+20 Konferentziako amaierako dokumentuan [11] ezarritako lehentasunezko zazpi 
eremuetako bigarrena. Dokumentu horretan esaten da oinarrizko giza premiei erantzuten laguntzeko ezinbestekoa dela energia eskuragarri izatea, efizientzia energetikoa hobetzea, eta energia berriztagarrien eta ez hain kutsakorren proportzioa handitzea. Ez da harritzekoa, beraz, Garapen Iraunkorrerako 7. Helburua energiari eskaini izana.

7. GIHak bilatzen duena honela laburbil daiteke, bi hitzetan, modu kualitatiboan: munduko biztanle ororentzat energia «eskuragarria» (1) eta «ez-kutsakorra» (2) hornitzea [12]. Haatik, Nazio Batuen webgune ofizialean, bi ñabardura gehitzen zaizkio: «fidagarria» (3) izatea, hots, epe luzera agortzeko arazorik ez egotea, eta «modernoa» (4) izatea, azken hori efizientziarekin loturik [4].

\subsection{Literatura berrikusten: 7. GIHaren analisia eta jarraipena}

Oraingoz ez dira ugariak 7. GIHaren analisia eta jarraipena zehazki lantzen duten azterketak, eta artikulu gutxi argitaratu da gaiaren inguruan. GIHen jarraipenari dagokionez, badira 17ak orokorrean tratatzen dituzten hainbat ikerlan, eta haietako batzuk aztertu dira, ematen dituzten ondorioak 7. GIHrako ere aplikagarri direla aintzat hartuta.

Barbier eta Burgessek [13] zenbait herrialdetako gobernuek ezarritako GIHen adierazleak aztertu dituzte, antzekoak eta/edo osagarriak ote diren ikuste aldera. Haien arabera, orain arte GIHen ebaluazio kuantitatiboa egin da ia osoki, eta esparru horretan egindako lana hiru gai hauetan zentratu da hein handi batean: helburu bakoitzerako xede eta adierazle egokiak formulatzea; lorpen orokorraren jarraipena egiteko neurketak diseinatzea; eta informazio ulergarria eta fidagarria batzea. Azpimarratu dute helburu bakoitzerako adierazle egokiak hautatzea eta adierazleen garrantzia ebaluatzea ezinbestekoa dela GIHak eraginkorrak izan daitezen, eta orobat azpimarratu dute orain arte egindako ahaleginak hainbat muga izan dituela. Izan ere, GIHak lortzeko bidean egindako aurrerapenak neurtzea zaila da; besteak beste, ez dagoelako helburu bakoitzak barne hartzen dituen xedeak kuantifikatzeko datu-iturri bakar bat eta kasu batzuetan ezinezkoa delako haien jarraipena egiteko informazio fidagarria topatzea. Aukeratutako adierazleen eta kalkuluak egiteko moduaren arabera, era bateko edo besteko emaitzak lortuko dira, hainbat faktorek (adierazleen ehunekoen aldaketak kalkulatzen diren, aurrerapena termino absolututan edo erlatibotan neurtzen den, helburuen lorpen-maila edo balio-aldaketa ikusten den, adierazle positibo edo negatiboak diren) edota faktore horien konbinazioak baldintzatuta.

2019ko beste ikerlan batean [14], estatu-mailan GIHen lorpenaren bilakaera neurtzeko erabiltzen diren hiru metodo nagusiak konparatu zituzten: GIHen Indizea (Bertelsmann Fundazioak eta Sustainable Development Solutions Network - SDSN - ekimenak elkarlanean garatua), Ekonomia Lankidetza eta Garapenerako Antolakundearen metodoa, eta Europar Bata- 
suneko Estatistika Bulegoarena. Metodook 17 GIHetarako adierazleak erabiltzen dituzte, eta herrialdeen ranking edo zerrendak osatzen, hainbat adierazleren emaitzak estatistikoki landu eta herrialde bakoitzari puntuazio bat esleituz. Konparaketa egiterakoan, metodoen arteko desadostasun handiak hauteman zituzten, eta ondorio esanguratsuetara iritsi ziren: herrialde baten emaitzak aukeratutako adierazleen eta aplikatutako metodoaren mende daude ia osoki. Hori, berez, aurreikustekoa zen, adierazle bakoitzak gauza bat neurtzen duelako, eta adierazleen aukeraketak lehentasunak ezartzen dituelako. Ikerlanaren egileen ustez, ikuspuntu politikotik zailtasunak ekar ditzake askotariko adierazle-multzoak egoteak, metodo ezberdinen emaitzak batera ikusteak nahasmena sor dezakeelako, eta uste dute adierazleak eta haien xedeak aukeratzea oinarrizkoa dela GIHen lorpena neurtzeko orduan. Xedeak aukeratzea da bereziki garrantzitsua; izan ere, GIHetako asko ez daude modu kuantitatiboan definituta. GIHen adierazleak 2030 Agendan zehaztutako xedeekin ahalik eta gehien lerrokatu behar dira, eta herrialde bakoitzeko testuinguruaren arabera adierazle batzuk edo beste batzuk izan daitezke aproposak. Nazio Batuek GIHen lorpena neurtzeko zehaztutako adierazle guztiak sarean eskuratu daitezke, Global SDG Indicators Database atalean [15], eta, urteek aurrera egin ahala, 2030 Agendaren jarraipena fintzen ari da, nahiz eta adierazle guztiek ez izan oraindik garapen metodologiko eta datuen eskuragarritasun bera, eta nahiz eta hiru multzotan mailakatuta egon Tier sistemaren arabera [16].

Swain eta Karimuk, energia berriztagarriek GIHak lortzeko bidean izan dezaketen eragina aztertu ostean, argudiatu dute lurralde bakoitzaren energia-sistemak eragin garrantzitsua duela garapen iraunkorrean eta hiru alorretan egin daitezkeen aldaketa teknologikoen mende dagoela eragin hori: energia aurreztea, energia era efizienteagoan erabiltzea eta erregai fosilak energia-iturri berriztagarriekin ordezkatzea [17]. Horregatik, hiru aldagai horiek kontuan hartu behar lirateke 7. GIHaren xede eta adierazleak finkatzeko orduan. Horrez gain, 7. GIHaz aparte energiarekin estuki lotuta dauden beste helburu batzuk ere badirela azpimarratu dute: 8 . GIHa (lan duina eta hazkunde ekonomikoa), 9. GIHa (industria, berrikuntza eta azpiegiturak), 12. GIHa (ekoizpen eta kontsumo arduratsua) eta 13. GIHa (klimaren aldeko ekintza). Hori dela eta, energia 2030 Agendan aztertzerakoan, analisi osatua egin nahi badugu, 7. GIHaz gain harekin lotuta dauden beste GIH horiek ere kontuan hartzekoak dira, eta helburu horietarako finkatzen diren xede eta adierazleek beren artean koherenteak izan beharko dute, energiari lotutako neurriei dagokienez.

\subsection{Ikerketaren ildoa}

Agenda ezartzeko eta praktikara eramateko lana askotariko gobernuen eta administrazio publikoen esku geratu da nagusiki. Hala, 17 GIHak lurralde bakoitzera egokitzeko plan edo bide-orriak martxan jarri dira [18], 
Nazio Batuen Erakundeak helburuotarako definitu zituen xede eta adierazleak tokiko errealitatera egokituz, lurralde bakoitzeko behar, ahalmen eta lehentasunen arabera. Zehazki, 17 GIHetarako xede propioak ezarri dira plan horietan, xedeen jarraipenerako adierazleak eta datu-iturriak zehaztu (gehienetan estatistika-bulegoen bitartez), eta, hainbat kasutan, jarraipena egiteko metodologiak eta lortutako emaitzak zabaltzeko erremintak diseinatu eta martxan jarri dira (txostenak, bestelako argitalpenak, webguneak).

Artikulu honen oinarrian dagoen lanak bi zati nagusi ditu: batetik, 7. GIHaren analisiari eta jarraipenari buruzko literaturaren berrikuspena; eta, bestetik, 7. GIHa betetzeko hainbat eragilek ezarri dituzten xedeen eta haien jarraipena egiteko definitu dituzten adierazleen azterketa. Egiturari dagokionez, lau atal nagusitan banatuta dago: lehen atal honetan, ikerketaren ildoa zehaztu da; bigarrenean, jarraitutako metodologia deskribatuko da; hirugarrenean, egindako analisiaren emaitzak laburbilduko dira, bi azpiatal bereizitan (batetik, 7. GIHaren xedeen konparaketa egingo da, eta, bestetik, xede horien lorpena neurtzeko adierazleena); eta, laugarren atalean, hausnarketa eta ondorio nagusiak plazaratuko dira, 7. GIHaren argiilunak agerian utziz.

\section{METODOLOGIA}

Ikerlana egiteko, dinamika sozialen konplexutasuna aztertzeko gai den Multi Level Perspective (MLP) erako metodologia erabili da [19]. Trantsizio sozioteknikoen dinamikak hiru dimentsiotan aztertzeko metodologia kuantitatibo sakon gisara definitzen du Geels-ek [20]. MLP metodologia eztabaida akademiko zabalean kontrastatu da [21], energia- eta politikaalorretan erabiltzen da bereziki. Horrez gain, eztabaida kulturala eta marko nazionalak, oinarrizko berrikuntzak, trantsizio-bideak nahiz krisiak eta ezegonkortzeak aztertzeko tresna gisa erabili izan da MLPa [21].

MLP metodologiak, alde batetik, badu «eredu global»en osagarria, eskala-maila askotan aztertzen baitira gaiak. Bestetik, «eredu lokal»aren azterketa osagarria ere badu, eta, hor, «berrikuntza erradikalak» behatzeak lekua har dezake, kasu zehatzetan jazotzen diren ekintzen mekanismo kausalak eta eskalen arteko interakzioak kontuan hartuz [22]. Metodologia horrekin, makro mailan (landscape, edo ingurua), meso mailan (regimes, edo erregimena) eta mikro mailan (niche, edo kasuak) aztertu dira 7. GIHaren bi alderdi: zenbait eragilek zehaztutako xedeak eta helburuaren lorpenaren jarraipena egiteko adierazleak. Ikerketak barne hartutako eragileak hiru eremu edo mailatako gobernuak izan dira: Nazio Batuak, Espainiako estatua, eta Euskadi edo Euskal Autonomia Erkidegoa (EAE).

Metodologia horren bidez, Europako mailatik EAEko mailaraino helburu berberak betetzeko dauden xede eta adierazleak alderatu dira. 


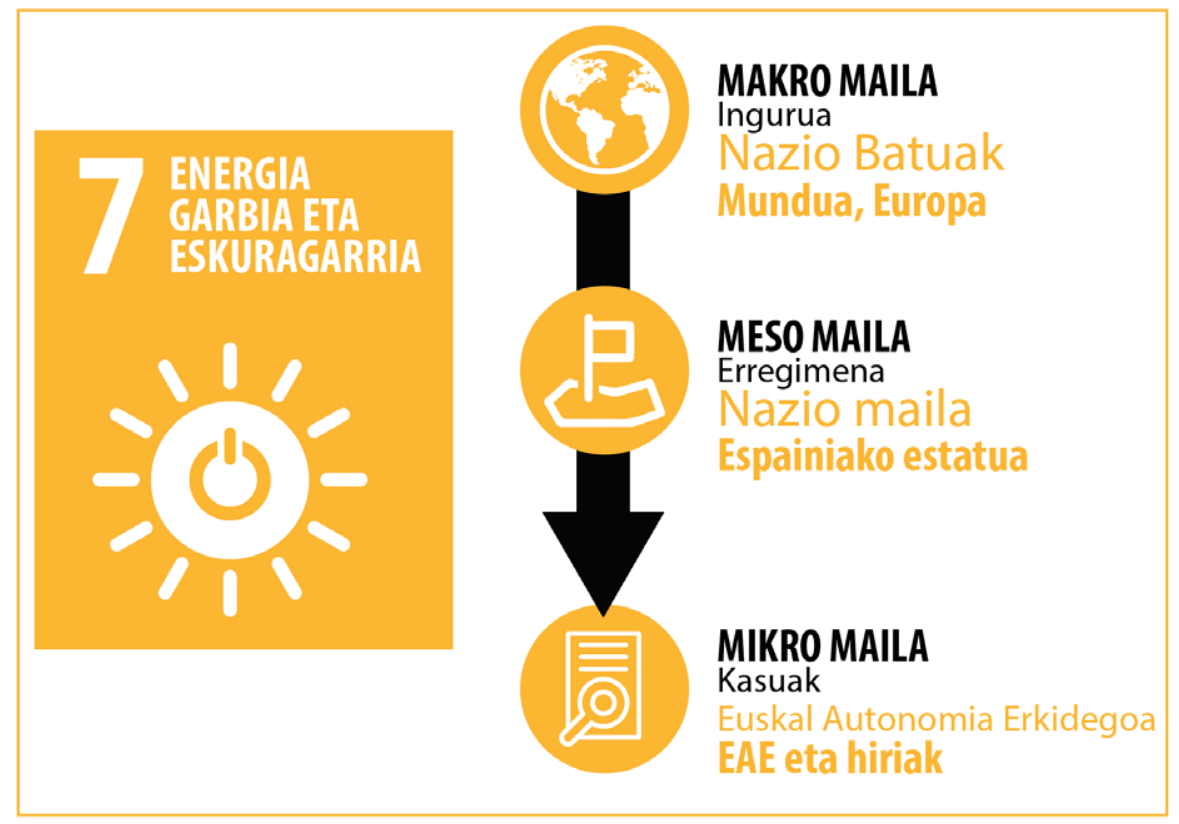

1. irudia. MLP metodologia erabili da ikerketa hau egiteko.

Metodologia hori aplikatzean, lehenik eta behin, 7. GIHari buruzko artikulu zientifikoak bilatu eta aztertu dira, Elsevier argitaletxean hitz gakoen bidezko analisia eginez [23]. Bestalde, aztertutako eragileek publikoki eskuragarri dituzten GIHei buruzko webguneak eta txostenak arakatu dira. Azterketaren helburu nagusia 7. GIHa ezartzeko eragileek zer planteamendu egin duten aztertzea izan da, eta zehaztu dituzten xede, adierazle eta jarraipenerako metodoak konparatzea. 1. irudian, era eskematikoan ikus dezakegu MLP metodologiaren eskala nola ezarri den ikerketan, Europa mailatik EAEko eta hiri mailako kasuetara.

\section{EMAITZAK}

\subsection{Zazpigarren GIHaren xedeen konparaketa}

Nazio Batuek 7. GIHrako makro mailan planteatzen dituzten xede edo helmugak bost dira: eskuragarritasun unibertsala (7.1), energia garbien erabilera (7.2), efizientzia energetikoa (7.3), nazioarteko ikerkuntza (7.a) eta garapen bidean dauden herrialdeetako azpiegitura eta teknologia (7.b) Xede horien artean, badaude bi motatakoak: emaitzekin lotutakoak (lehen hirurak, zenbaki hutsez zenbakitutakoak) eta ezarpen-baliabideekin lotu- 
takoak (azken biak, letren bidez zenbakituta). Nazio Batuek enuntziatu bezala azaldu ditugu 1. taulan.

Europan eta Espainiako estatuan, makro eta meso mailetan, Nazio Batuekiko estandarizazioa guztizkoa izan da 7. GIHari dagokionez, eta xede berberak aukeratu dira [24]. Europar Batasunak konpromisoa hartu du GIHak ezartzeko barneko eta kanpoko politiketan, eta Europako Batzordearen 10 lehentasunetan txertatu ditu, zeharka [25]. Espainiako Gobernuak 2030 Agenda ezartzeko plana egin zuen 2016an, eta agenda horrek GIHak betetzen saiatzeko mekanismoak eta koordinazio-tresnak jasotzen ditu [26].

Eusko Jaurlaritzak «Agenda Euskadi Basque Country 2030» izeneko bide-orria egin zuen 2016an, eta horrek erakusten du nolako lerrokatze- eta ekarpen-maila zuten orduko gobernu-programak eta hura osatzen zuten sektore-politikek 17 GIHen erronkei dagokienez [27]. Bide-orri horretan, 7. GIHrako lau helmuga edo xede, hiru adierazle, Euskadiko Energia Estrategia 2030 plangintza-tresna eta bi ekimen legegile finkatu zituzten: Mugikortasun Jasangarriaren Lege Proiektua, eta Administrazio Publikoen Jasangarritasun Energetikoari buruzko Lege Proiektua [28]. Euskadik 7. GIHrako ezarritako xedeetan, gasaren erabileraren garrantzia aipatzen da, energia berriztagarrietarako «trantsizio-energia» edo bide gisa [27].

Agendaren maila anitzeko izaera eta EAEko eskumenen banaketa direla eta, lurralde horretan agenda ezartzeko orduan, beste administraziomaila hauek ere aztertu beharrekoak dira: foru-aldundiak eta udalak. Izan ere, EAEko hiru foru-aldundiek martxan jarri dituzte 2030 Agenda ezartzeko bide-orriak; horrez gain, udal askok agendarekiko konpromisoa hartu dute, eta lehenengo urratsak egin dituzte, gobernu-planak GIHekin gurutzatu, politika publikoak eta gobernu-programak 2030 Agendarekin nola lerrokatzen diren aztertu eta diagnosia egiteko asmoz.

Foru-aldundien kasuan, Arabako Foru Aldundiak Garapen Jasangarriaren Aldeko Arabako Aliantzan parte hartzen du, eta konpromisoa hartu du «2030 Agenda eta GIHak egikaritzeko ekimenen alde egiteko eta haien zabalkundean eragiteko» [29], baina oraindik ez du xede edota adierazle propiorik definitu. Bizkaiko Foru Aldundia ere antzeko egoera batean dago; Gipuzkoako Foru Aldundiak, aldiz, Ingurumeneko Zuzendaritza Nagusiaren eta Gipuzkoako Jasangarritasunaren Behatokiaren bidez, adierazle-sistema bat definitu zuen, 2030 Agendan ingurumen-xedeak lortzeko bidean Gipuzkoaren aurrerapen-mailaren jarraipena egin ahal izateko eta lorpenen inguruko txostenak argitaratzeko. Sistema horrek 51 adierazle barne hartzen ditu, hamalau GIHrekin lotutako 43 xederi dagozkienak [30].

1. taulan, GIHaren 5 xedeen azterketa-mailak bereizita erakusten dira: elektrizitaterako sarbide unibertsal eta modernoa, energia berriztagarrien 


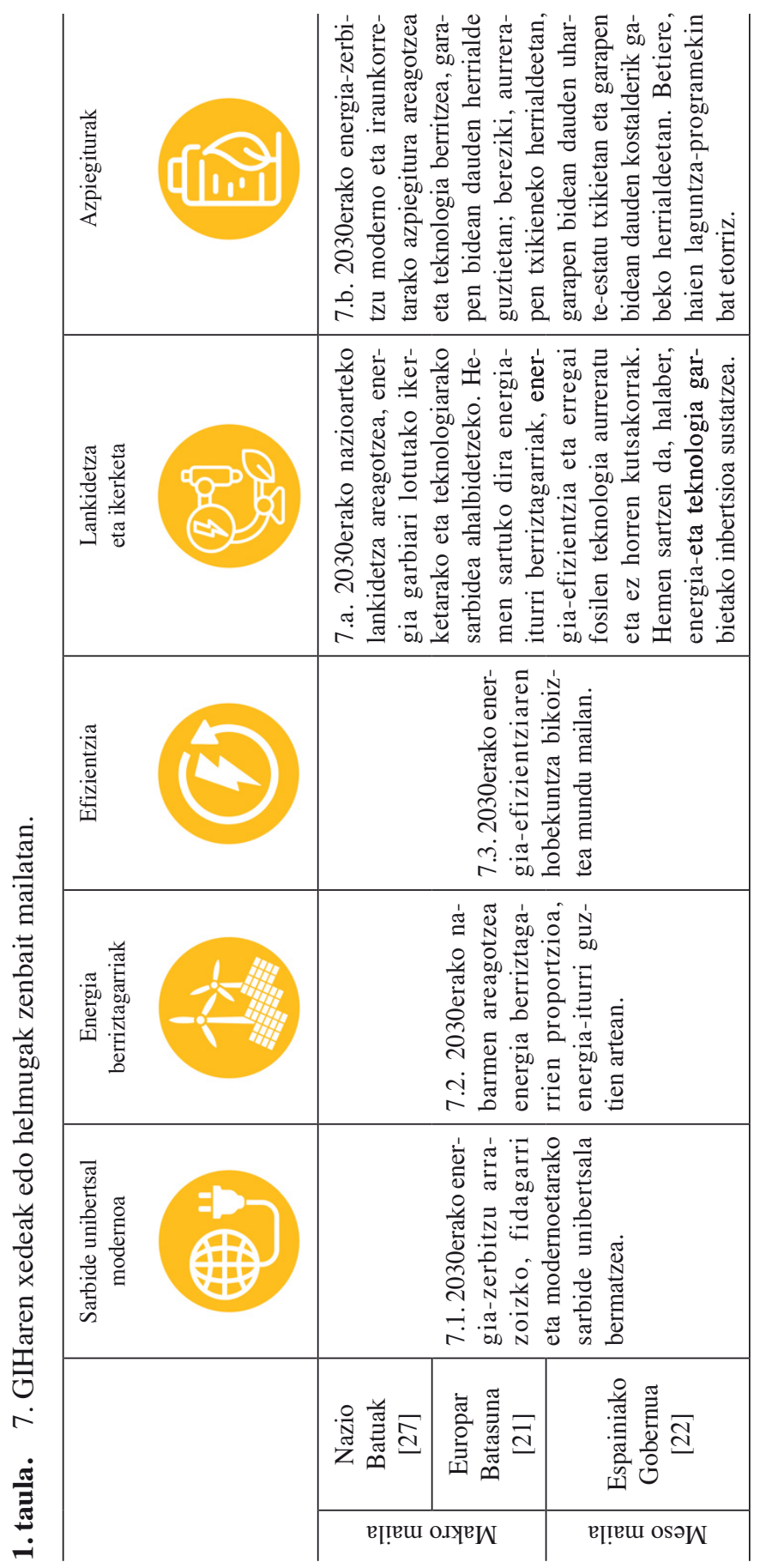




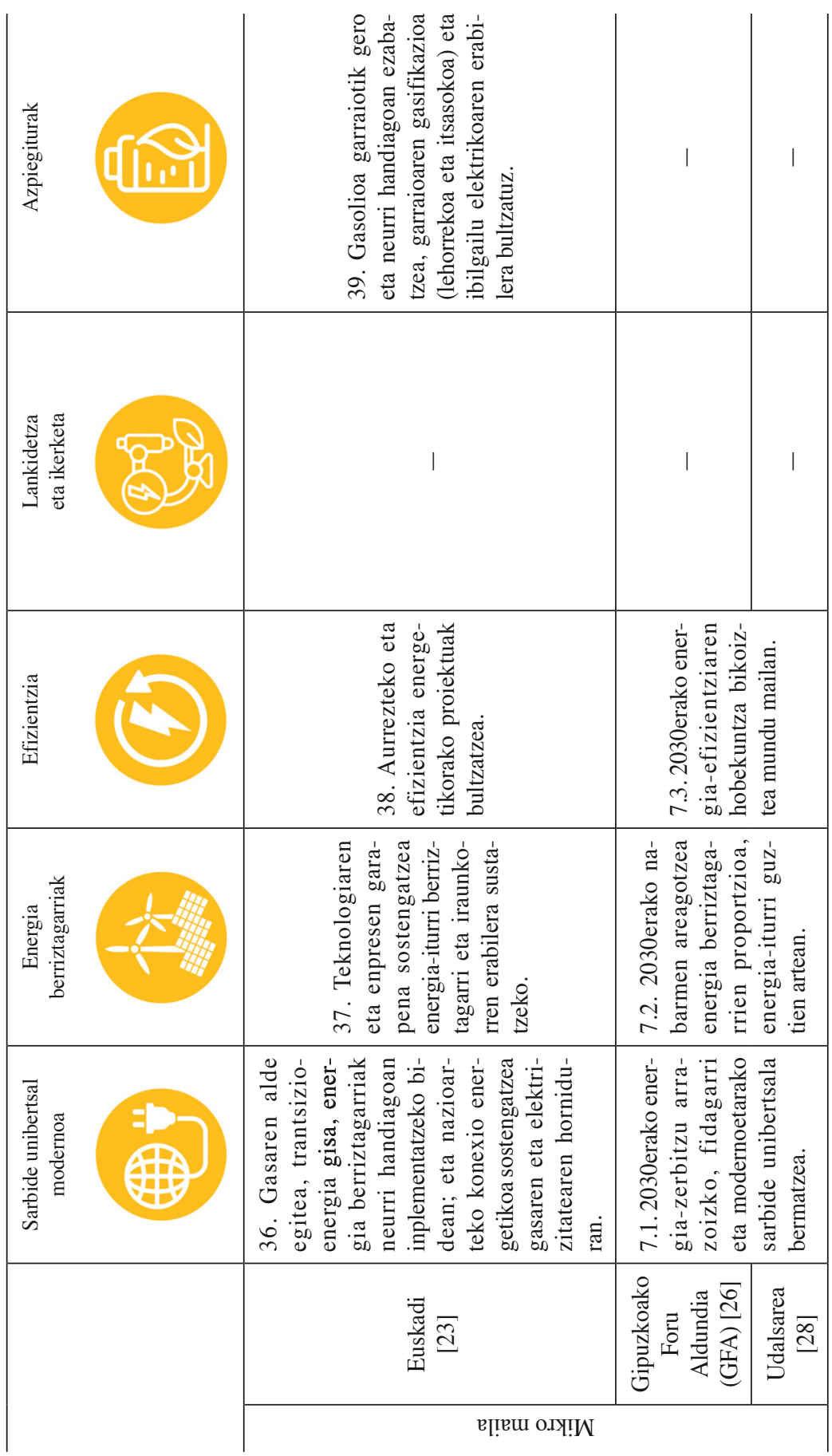


erabilera, efizientzia energetikoa, lankidetzaren eta ikerketaren beharra, eta, azkenik, azpiegitura energetikoen gauzatzea. Udalen kasuan, administrazio publikoek bidelagun izan dituzte 2030 Agenda eta GIHak betetzea bultzatu nahi duten eragileak. Haietako bi dira REDS (Red Española para el Desarrollo Sostenible) eta Udalsarea, Espainiako estatuan eta Euskadin, hurrenez hurren, biak ere udalei laguntzeko lana egin dutenak. Bai udalek eta baita Gipuzkoako Foru Aldundiak ere bere horretan hartu dituzte 7. GIHaren emaitzekin lotuta dauden Nazio Batuen hiru xedeak (7.1, 7.2 eta 7.3). 1. taulako konparaketan, bistan denez, aztertutako eragile guztiek, Eusko Jaurlaritzak izan ezik, Nazio Batuek ezarritako xede berberak sartu dituzte beren planetan.

\subsection{Zazpigarren GIHaren adierazleen konparaketa}

Makro mailan, Nazio Batuek bi jarraipen-esparru ezarri dituzte, elkarren aldean desberdinak eta elkarren osagarriak, urtero argitalpen banatan GIHen munduko egoera erakusteko: 1) munduko adierazleen esparrua, Garapen Iraunkorrerako Helburuen Txostenean biltzen dena, eta 2) GIHen arteko lotura, integrazio eta elkarrekintzen esparrua, Garapen Iraunkorraren Txosten Globalean biltzen dena [31].

Horrez gain, makro mailan hau ere, 2019an, urtero 7. GIHaren jarraipena egiteko txosten bat argitaratzen hasi ziren Energiaren Nazioarteko Agentzia, Energia Berriztagarriaren Nazioarteko Agentzia, Nazio Batuen Estatistika Atala, Munduko Bankua eta Osasunaren Mundu Erakundea, elkarlanean [32]. Txosten horretan, energia berriztagarrien integrazioan emandako aurrerapausoak aztertu zituzten, estatuen energia-kontsumoaren murrizte-tasa neurtu, kozinatzeko energia garbiaren gabezia duten herrialdeen zerrenda eta sailkapena eguneratu, eta estatuen energia-subiranotasunaren mailari erreparatu [33].

Europari dagokionez, Europar Batasuneko Estatistika Bulegoak (EUROSTAT) hartu du GIHen jarraipena egiteko ardura. Haatik, 2030 Agenda sortu zenetik, herrialdeek indarrak batu dituzte GIHak neurtzeko estatistika-lanetan elkarri laguntzeko. 2015eko Europako Estatistikarien Konferentziaren ondoren, 2018an, estatistika-bulego nazionalek, Nazio Batuen Europarako Batzorde Ekonomikoaren GIHen Jarraipenerako Estatistikei buruzko Zuzendaritza Taldearekin elkarlanean, herrialdeetan adierazleak ezartzeko eta haien jarraipen estatistikoa egiteko sistema abiarazten laguntzeko bide-orria diseinatu eta argitaratu zuten, eta, 2020an, Towards achievingthe Sustainable Development Goals in the UNECE region. A statistical portrait of progress and challenges lana argitaratu zuten, zeinak ordutik honako aurrerapenak biltzen baititu [25]. 
Energia 2030 Agendan eta Garapen Iraunkorrerako Helburuetan:

7. GIHaren xede eta adierazleen analisia Euskal Autonomia Erkidegoan

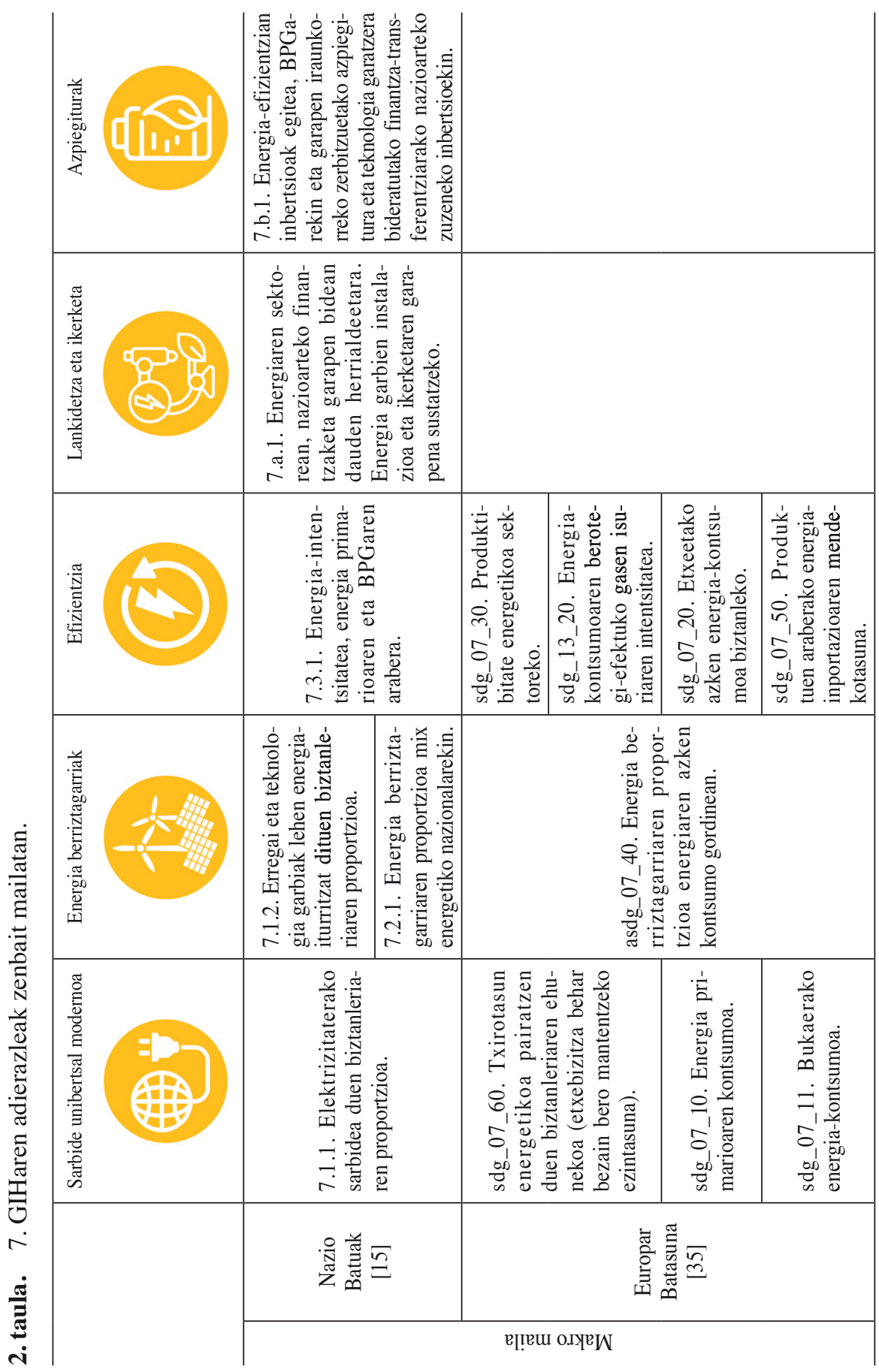

https://doi.org/10.1387/ekaia.22093 


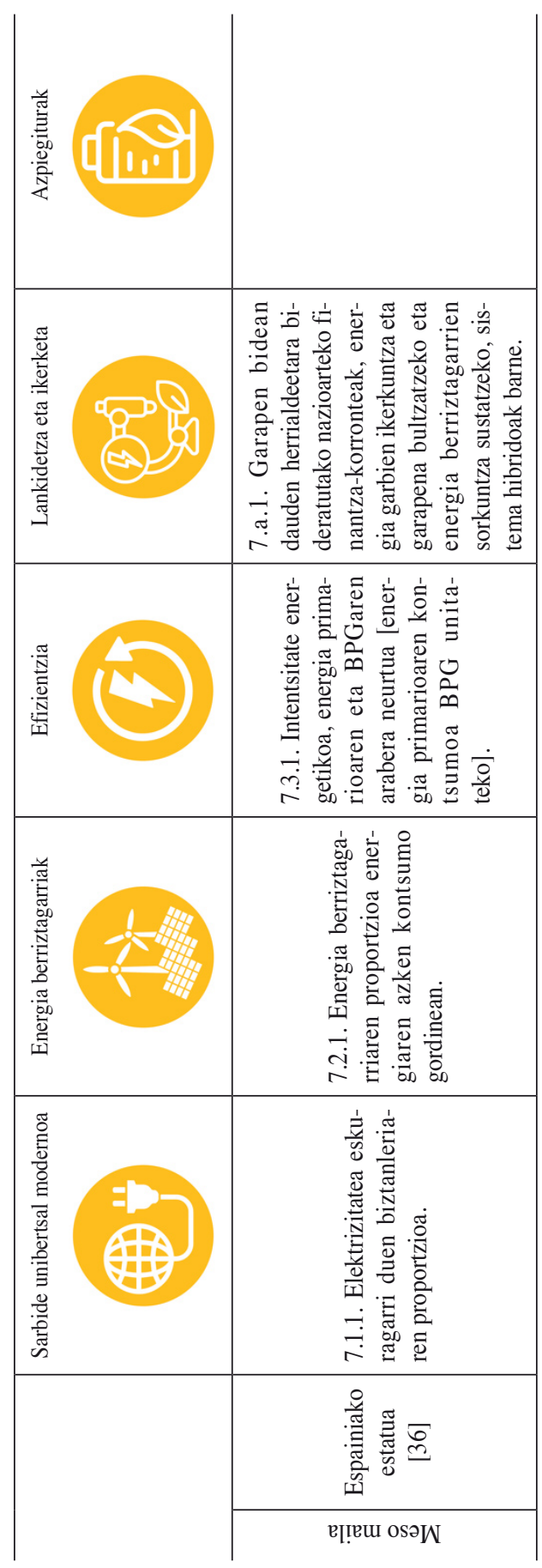


Energia 2030 Agendan eta Garapen Iraunkorrerako Helburuetan:

7. GIHaren xede eta adierazleen analisia Euskal Autonomia Erkidegoan

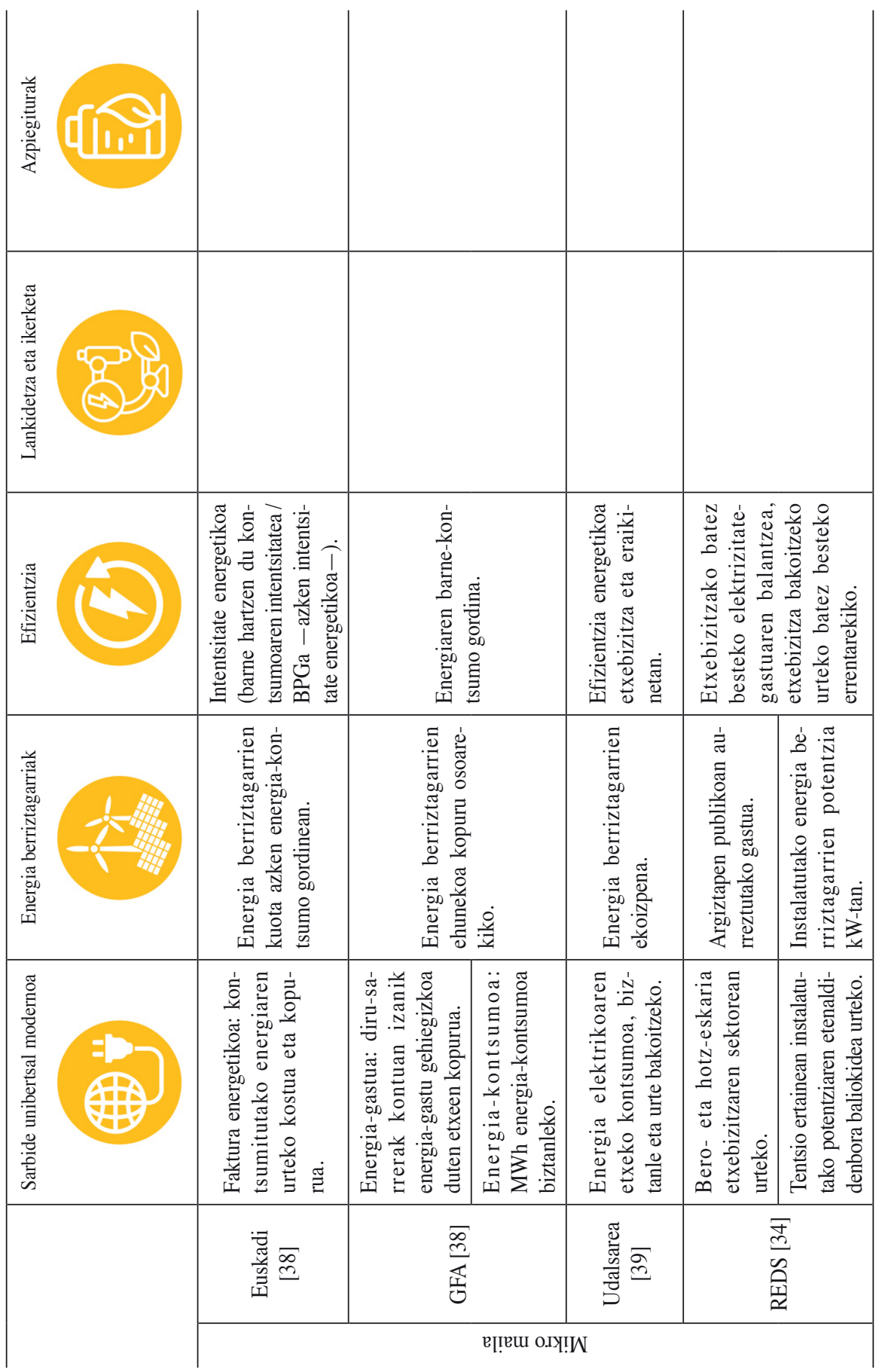

https://doi.org/10.1387/ekaia.22093 
Nazio Batuek 2012an abiarazi zuten SDSN ekimena, eta Fondazione Eni Enrico Matteik (FEEM) egin du 7. GIHaren hainbat adierazleren jarraipena. Emaitza gisa, argindarrik gabeko munduko populazioaren mapa argitaratu zen [34]. SDSN ekimenaren Espainiako estatuko REDS adarrak udal-mailan GIHen jarraipena egiteko adierazleak proposatu ditu Los Objetivos de Desarrollo Sostenible en 100 ciudades españolas argitalpenean [35], eta datozen urteetan haien araberako jarraipena egitea du helburu. Ihobek, Udalsarearekin elkarlanean [36], GIHei tokiko eremutik nola heldu azaltzen duen gida praktiko bat jarri du udalen eskura, Tokiko 2030 Agenda diseinatu ahal izan dezaten, jarraipenerako adierazleak barne.

Eusko Jaurlaritzak 2019an argitaratutako datuen arabera, EAEn, ordura arte 17 udalerrik abiatu zuten energia jasangarrirako ekintza-plan bat (EJEP). Udalerri horietan, etxebizitzetako batez besteko kontsumo elektrikoa biztanleko eta urteko EAEko orokorra baino \% 6 txikiagoa da, eta energia berriztagarrien sorkuntza EAEkoa baino \% 6 handiagoa [36].

1. taulako xedeen lorpenak 2. taulako adierazleekin neurtu nahi dituzte aztertutako eragileek, eta irudietan (2-7 irudiak) ikus dezakegu adierazle horien bilakaera nolakoa izan den 2000-2017 aldian. Munduko eta Europako (makro maila), Espainiako estatuko (meso maila) eta EAEko zein hiriburuetako (mikro maila) adierazleen jarraipena egiteko informazioa datuiturri ofizialetatik jaso da.

Mundu mailako adierazleei dagokienez, 2030ean elektrizitate gabia eskuragarri izateko xedea bete daitekeela diote hainbat erakundek, baldin eta urtero \% 0,86ko igoera-tasa bermatzen bada, eta hori bideragarritzat jotzen da, 2015-2017 biurtekoan batez besteko igoera tasa \% 1,04koa izan baitzen [32]. Gaur egun, 7.1 adierazlearen arabera, munduko biztanleen $\% 63 \mathrm{k}$ du energia garbia eskuragarri [15].

2. irudian, Nazio Batuen bost adierazleren (7.1.1, 7.1.2, 7.2.1, 7.3.1 eta 7.a.1) eboluzioa ikus dezakegu, eta, 3. irudian, Espainiako estatuko birena (7.2.1 eta 7.3.1). Munduko egoera Espainiako estatukoarekin konparatuz, ikus dezakegu energia berriztagarrien integrazioa (7.2.1 adierazlea) $\% 17 \mathrm{koa}$ dela munduan eta \% 1 bakarrik igo dela aztertutako denboraldian, eta Espainiako estatuan, aldiz, egun integrazioa baxuagoa izan arren (\% 16), 2000. urtearekin konparatuta, \% 98 igo dela. Intentsitate energetikoari dagokionez (7.3.1 adierazlea), munduan 5 MJ/BPGko balioa du gaur egun, eta, azken urteotan, \% 24 jaitsita hobetu da; Espainiako estatuan, aldiz, egun $3 \mathrm{MJ} / \mathrm{BPGko}$ balioa du, eta jaitsiera \% 21ekoa izan da azken 17 urteetan. Gainerako adierazleei dagokienez, 7.1.1 eta 7.1.2 mundu mailan soilik lantzen dira, Europan eta Espainiako estatuan energia garbiaren eskuragarritasuna \% 100ekoa dela estimatzen baita; eta, «garapen bidean» dauden herrialdeetan egiten diren diru-inbertsioak (7.a.1 adierazlea) aintzat 
Energia 2030 Agendan eta Garapen Iraunkorrerako Helburuetan:

7. GIHaren xede eta adierazleen analisia Euskal Autonomia Erkidegoan

hartuta, ikus dezakegu munduan \% 1.469 igo dela kopurua eta gaur egun urteko 21,40 mila milioi dolar inbertitzen dela.

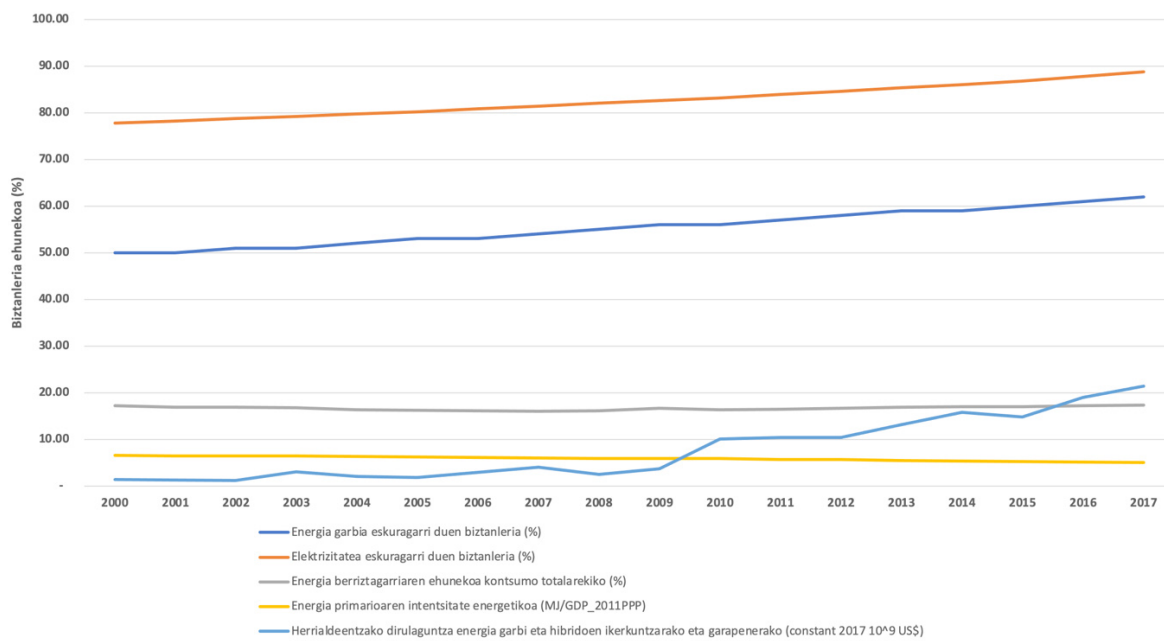

2. irudia. Mundu mailako adierazleak [15].

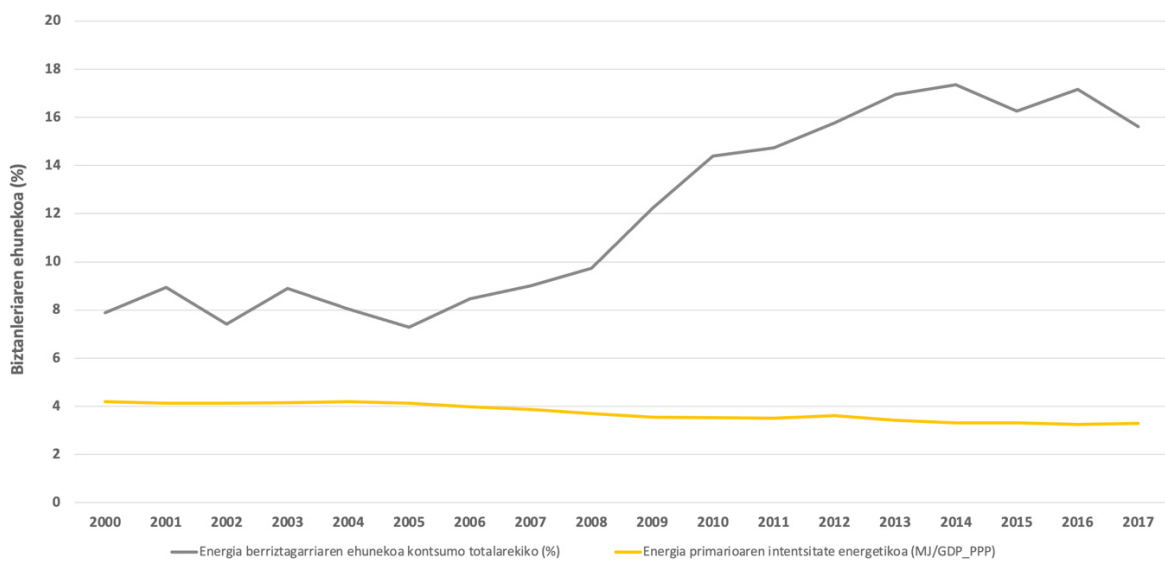

3. irudia. Espainiako estatuko adierazleak [15].

Europari dagokionez, 4. eta 5. irudietan ikus ditzakegu EUROSTATek emandako datuetatik abiatuta egindako grafikoak. Zortzi adierazle ditu EUROSTATek eskuragarri, eta Nazio Batuen bost adierazleek baino zehaztasun handiagoa eskaintzen dute. Europa mailako datuak mundu mailakoekin eta Espainiako estatukoekin alderatuz gero, ikus dezakegu Euro- 
pako energia berriztagarrien integrazioa (\% 19) handiagoa dela mundukoa baino (\% 17), nahiz eta berriztagarrien datuak EUROSTATen 2014. urtera arte bakarrik dauden eguneratuta eta Nazio Batuenak, berriz, 2017ra arte. Energia primarioaren kontsumoari dagokionez, azken 18 urteotan, \% 6 murriztu da, bai Europan, bai Espainian; halere, gaur egun, Espainiako estatuan 2,66 toe kontsumitzen dira pertsona eta urteko, Europako batezbestekoa baino \% 14 gutxiago. Energia primarioaren eta amaierako energiaren arteko aldea \% 30ekoa da Espainian eta \% 29koa Europan, eta horrek esan nahi du energiaren transformazioko galerak maila berekoak direla. Etxebizitzetan kontsumituriko energiari dagokionez, gaur egun Espainiako estatuan 321 ktoe kontsumitzen dira biztanle eta urteko, Europan baino \% 42 gutxiago; baina joerak oso ezberdinak dira, azken urteetan $\% 5$ jaitsi baita Europan, eta \% 8 igo, aldiz, Espainiako estatuan. Datuei erreparatuz, produktibitate energetikoa nabarmen igo da azken urteotan, bai Espainian, bai Europan, eta ktoe bakoitzeko lorturiko euroak bikoiztu dira.

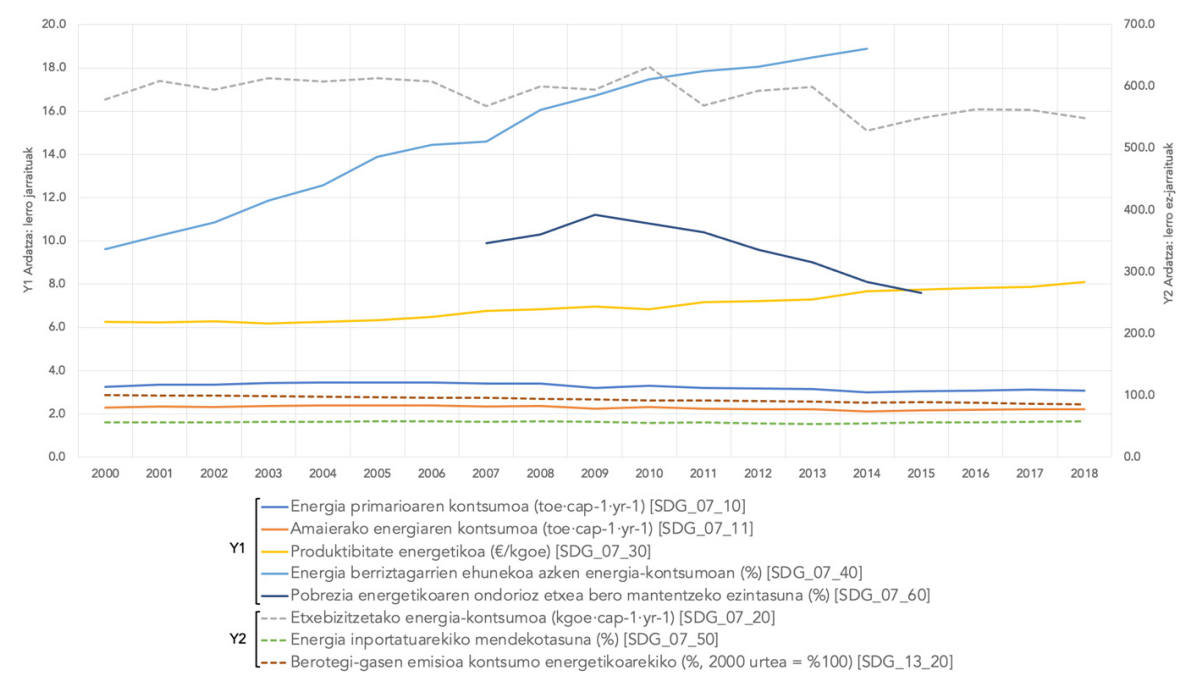

4. irudia. Europa-27 mailako adierazleak [37]. Lerro jarraituetan adierazitako adierazleek ezkerreko Y1 ardatzari jarraitzen diote; lerro ez-jarraituan adierazitakoek, berriz, eskuineko Y2 ardatza.

Energia inportatuari erreparatuta, ikusten dugu Espainiako estatuan $\% 5$ jaitsi den arren energiaren $\% 73$ atzerritik ekarria dela oraindik, Europan baino \% 26 gehiago. Pobrezia energetiko termikoari dagokionez, kontsideratzen da azken urteotan Espainian \% 21 jaitsi den arren biztanleen $\%$ 7,5ek arazoak dituztela oraindik etxebizitza bero mantentzeko, Europan baino \% 20 gehiagok. Azkenik, berotegi-efektuko gasen isuriak \% 17 jaitsi dira Espainian aztertutako denboraldian, Europaren antzera. 


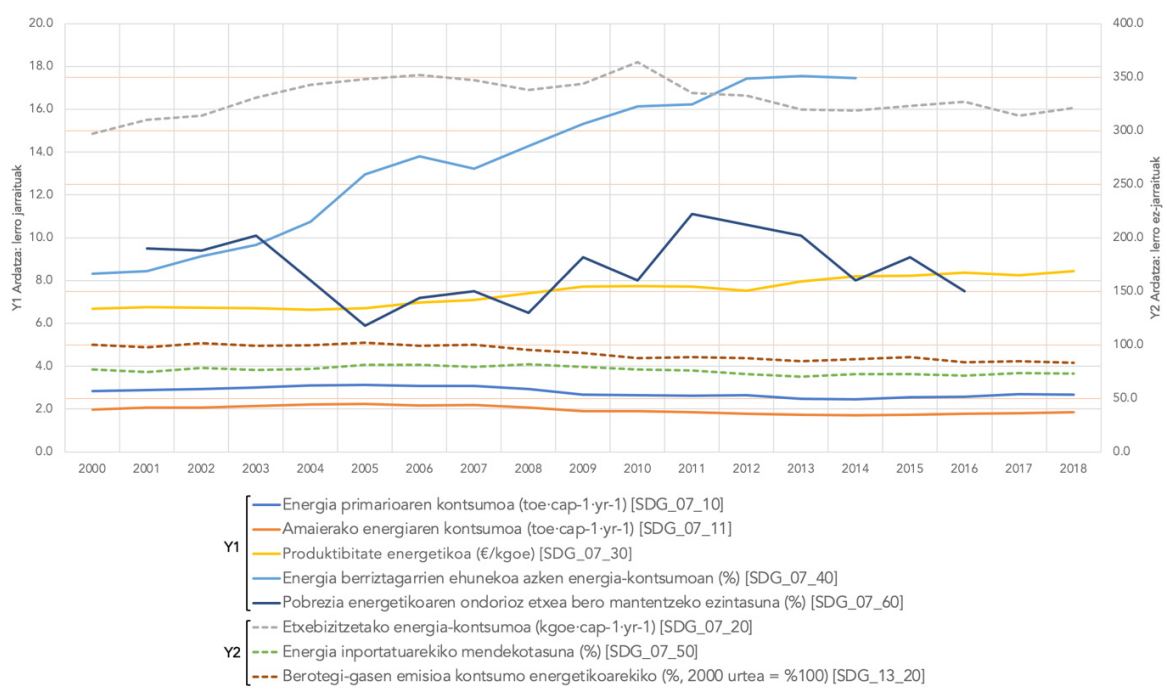

5. irudia. Espainiako adierazleak [37]. Lerro jarraituan adierazitako adierazleek ezkerreko Y ardatzari jarraitzen diote; lerro ez-jarraituan adierazitakoek, berriz, eskuineko Y ardatzari.

Mikro mailara etorrita, EAEko adierazleen eboluzioa aztertzeko EUSTATen datuak kontsultatzean, aipatzekoa da, Nazio Batuek eta EUROSTATek eskaintzen dituzten datuak ez bezala, ez daudela hain eskuragarri. Ez daude prestatuta erabiltzaile ez-aditu batek bilaketa bakar batean erraz aurkitzeko, eta ez da aipatzen zer lotura duten Nazio Batuen 7. GIHaren adierazleekin (7.1.1, 7.1.2, 7.2.1, 7.3.1, 7.a.1 edota 7.b.1); horrenbestez, konparaketak egitea zailagoa da. Bestalde, lau adierazle besterik ez ditu EUSTATek 7.GIHrako, Nazio Batuek eta EUROSTATek baino bi eta lau gutxiago, hurrenez hurren. Eskuratutako datuekin grafikoa osatuz ikus dezakegu energia berriztagarrien integrazioa \% 17koa dela EAEn, mundukoaren ehuneko bera eta EU27-koa baino baxuagoa. Bestalde, kontsumo primarioa $\% 4$ jaitsi da azken 18 urteetan, eta energia-intentsitatea $\% 21$ hobetu. $\mathrm{CO}_{2}$ isuriei dagokienez, \% 11 egin dute behera azken 16 urteetan. Aipatu behar da, emanda datozen unitateen ondorioz, batez ere aurreko urteekiko ehuneko erara eskainita egotearen ondorioz, ezinezkoa dela hainbat iturritatik jasotako datuak alderatzea. 


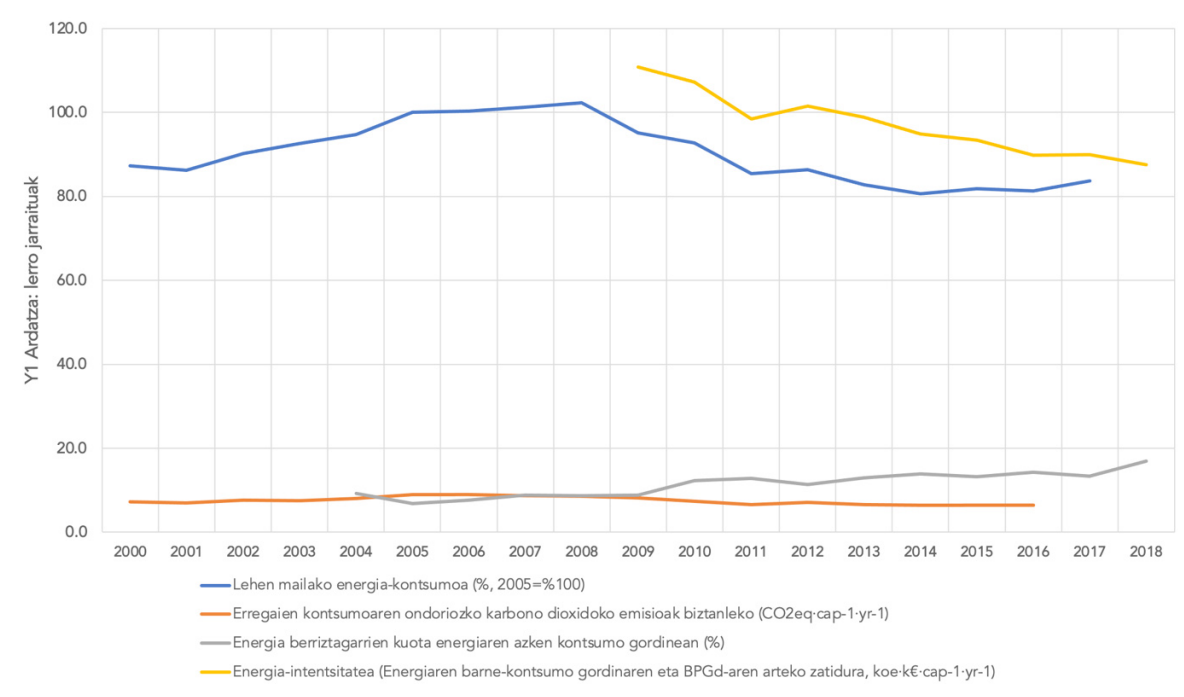

6. irudia. EAEko egoera energetikoaren adierazpen bidezko irakurketa [38]. Adierazlean ez daude 7. GIHen multzo batean sartuta, baina ikerketa honetarako elkartu ditugu.

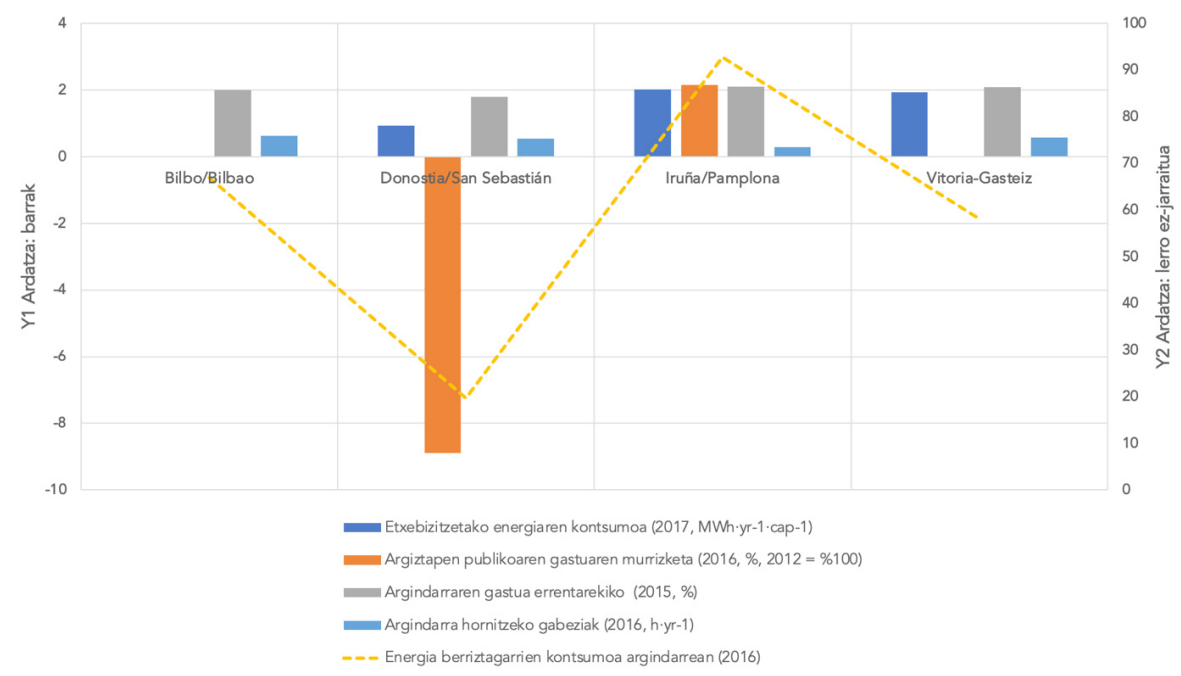

7. irudia. EAEko hiru hiriburuetako eta Iruñeko ezaugarri energetikoak. 7. GIHaren jarraipena [39].

Azkenik, REDSek eskainitako EAEko hiriburuetako datuak aurki ditzakegu 7. irudian. Ezin da joerarik ikusi, urte bakarreko datuak baizik. Datu 
horiek erakusten digute Gasteizkoa dela etxebizitzetako energiaren kontsumorik altuena, eta errentarekiko energia-gasturik handiena Bilbon eta Gasteizen ematen dela, Donostian baino \% 16 gehiago. Bestalde, energia berriztagarrien integrazioa Donostian \% 19koa dela adierazten dute datuek; Bilbon eta Gasteizen, aldiz, \% 60tik gorakoa. Horrek zalantzak sortzen dizkigu datuen fidagarritasunari dagokionez, eta/edo datuak bildu dituztenek adierazlea interpretatzeko moduari dagokionez. Argiztapen publikoan aurreztutako gastuari dagokionez, hiru hiriburuetako datuak eskuragarri egon ez arren, ikus daiteke Donostian ahalegin berezia egin dela sektore horretan.

\section{HAUSNARKETA ETA ONDORIOAK}

2030 Agendak indarrean daramatzan bost urteotan, hari buruzko analisi anitz egin dira. Haietako askok 2030 Agendak garapen iraunkorraren alde ekintza kolektiboak bideratzeko duen potentzialtasuna azpimarratzen dute, eta hain ugariak ez diren beste analisi batzuek haren mugak eta kontraesanak aipatu dituzte, potentzial transformatzailea txikitzen duten heinean. Martínezen aburuz [18], bost dira 2030 Agendaren alde on azpimarragarrienak: unibertsala eta globala izatea (mundu osoari aplikagarri); dimentsio anitzeko akzio kolektiboa bultzatu nahia; izaera integrala (ekintza politikoaren izaera zatituaren kontrara); maila anitzetan eragin nahia (mundu, kontinente, herrialde, lurralde, erkidego, udal, komunitateetan); askotariko eragileak nahastea eta horrenbestez erantzukizun partekatuak ezartzea jendarte globaleko parte direnei.

Aurretik mundu mailan zeuden arazoen diagnostiko osatuago bat ekarri duen arren, ukaezinak dira 2030 Agendak piztu dituen kritikak, adostu den moduari, barne hartzen dituen inkoherentziei eta ezartzeko edo praktikara eramateko azaltzen dituen zailtasunei buruzkoak [40]. Hala, aitortzen zaizkion balizko onurak aintzat hartuta ere, asko dira 2030 Agendari egiten zaizkion kritikak; besteak beste: etorkizunera begiratzea, arazoen zergatiak eta ikuspegi historikoa landu gabe, azken hamarkadetan zehar munduko herrialdeen garapena baldintzatu duten egiturak eta botere-harremanak aztertu gabe [41]; GIH ugari aldi berean lortzen saiatzea, kasu batzuetan kontraesankorra izan daitekeena, elkarrekiko duten eragina dela eta [42]; agenda betetzea borondatezko kontua izatea, ez derrigorrezko zerbait, eta ez ezartzea anbizio handiko helburu, xede eta adierazlerik [18].

Azken alderdi horri dagokionez, hainbat ahotsek diote oraindik ere jarraipen-esparrua, adierazleen definizioa eta hautaketa osatu eta doitu beharra dagoela, eta hobeto zehaztu behar direla gobernuentzako politika-aginduak eta -gomendioak [31]. Ikusi da nola 2030 Agenda meso eta mikro mailetara eramatean bi jarrera gailentzen diren gobernuen artean: batzuek martxan dituzten politika eta planak bere horretan lotzen dituzte GIHen xedeekin, inolako aldaketarik egin gabe, eta beste batzuek aldaketak eta 
hobekuntzak egiten dituzte beren politiketan, 2030 Agendak proposatzen duenarekin lerrokatzeko [40]. Lehen jarrera duten gobernuetan, ohikoa da inkoherentziak egotea GIHetarako zehaztu dituzten xede eta adierazle propioen eta Nazio Batuek ezarritakoen artean.

Eragileek 7. GIHrako ezarri dituzten xede eta adierazleak alderatu ditugu ikerlan honetan, bai era kualitatiboan, bai kuantitatiboan, eta mundu mailatik (Nazio Batuak) EAE mailara aztertu ditugu, MPL metodologia erabiliz. Xedeak orokorrean berdinak izan arren, ikusi da adierazleetan badaudela ezberdintasunak, kasu batzuetan nabariak, eta horrek eragileen arteko konparaketak egitea zailtzen duela. Meso mailatik beherako eragileek ez dute 7. GIHaren ezarpen-baliabideekin lotutako adierazlerik ezarri, eta horrek asko murrizten du helburuaren jarraipen osatua egiteko aukera, baita datu eskuragarri eta eguneratuen faltak ere. Horregatik guztiagatik, adierazleak estandarizatzen eta datu-iturriak hobetzen jarraitzeko beharra ikusten da.

Bestalde, 2000-2017 aldirako adierazleen analisian ikusi dugu orokorrean badagoela joera orokor bat energia primarioaren kontsumoa murrizteko baina ez dela gauza bera gertatzen etxebizitzetako elektrizitate-kontsumoarekin. Aipatu behar da, halaber, energia primarioaren kontsumoaren neurketan adierazleek ez dutela txertatzen aztarna energetikoaren neurketa eta, ondorioz, lurralde horietatik kanpora atera den ekoizpenaren kontsumo energetikoa ez dela aintzat hartzen. Beste lurralde batzuetatik ekarritako produktu eta zerbitzuek kontsumitzen duten energia ez neurtzeak energiakontsumoaren murrizketen inguruko interpretazio okerrak eragin ditzake, eta hori kontuan hartu beharreko gaia litzateke GIHen benetako lorpena neurtu nahi izanez gero $[43,44]$.

Energia berriztagarrien integrazioari dagokionez, bai Espainiako estatua bai EAE Europako batezbestekoaren atzetik daude, eta, EAEko hiriburuei dagokienez, ez dago argi aztertutako GIHen jarraipenerako txostenean emandako datuen jatorria.

Eskala txikian, hiri mailan, GIHen jarraipenerako datuen zehaztasuna galtzeak pertzepzio-arazoak sor ditzake gizartean, eta batez ere herri-politikak egin behar dituzten eragileengan. Aurreko guztiagatik, garrantzitsutzat jotzen da etorkizunean adierazleen estandarizazioan aurrerapausoak ematea.

\section{ESKER ONA}

Ikerketa hau honako ikerketa talde hauek lagundu dute: «EKOPOL: TRANSITION PATHWAYS», Eusko Jaurlaritzak (IT-1365-19) eta Euskal Herriko Unibertsitateak babestua (GIC-18/22), eta Hegoa Institutuaren GARAPEN ETA LANKIDETZAKO POLITIKEI BURUZKO IKERKETA TALDEA, Euskal Herriko Unibertsitateak babestua (GIU 17/26). 
Energia 2030 Agendan eta Garapen Iraunkorrerako Helburuetan:

7. GIHaren xede eta adierazleen analisia Euskal Autonomia Erkidegoan

\section{BIBLIOGRAFIA}

[1] COLOMBO, E., ROMEO, F., MATTAROLO, L., BARBIERI, J. eta MORAZZO, M. 2018. «An impact evaluation framework based on sustainable livelihoods for energy development projects: an application to Ethiopia». Energy Res. Soc. Sci., 39, 78-92, doi: 10.1016/j.erss.2017.10.048.

[2] CASTÁN BROTO, V. eta KIRSHNER, J. 2012. «Energy access is needed to maintain health during pandemics». Nat. Energy, 5, Art. no. 6, doi: 10.1038/ s41560-020-0625-6.

[3] NAZIO BATUAK. 2012. «A/RES/67/215. Promotion of new and renewable sources of energy». https://www.un.org/en/ga/search/view_doc. asp?symbol=A/RES/67/215

[4] NAZIO BATUAK. 2020. «UN, Goal 7 I Department of Economic and Social Affairs». https://sdgs.un.org/goals/goal7 (kontsulta eguna 2020/09/10).

[5] MANOLIS, E. eta MANOLI, E. 2021. «Raising awareness of the Sustainable Development Goals through Ecological Projects in Higher Education». J. Clean. Prod., 279, 123614, doi: 10.1016/j.jclepro.2020.123614.

[6] SACHS, J. D. 2012. «From Millennium Development Goals to Sustainable Development Goals». The Lancet, 379, 9832 zk., 2206-2211, doi: 10.1016/ S0140-6736(12)60685-0.

[7] UGARTETXEA, J., VILLALBA, U. eta VIOTA, N. 2017. «El derecho humano al medio ambiente en la Agenda 2030». UNESCO Etxea, Bilbo.

[8] VELO, E. 2006. «Desafíos del sector de la energía como impulsor del desarrollo humano». Cuadernos Internacionales de Tecnologías para el Desarrollo Humano, 5, 16.

[9] DFID. 2002. «Energy for the poor: underpinning the millennium development goals». https://www.eldis.org/document/A10869

[10] UN ENERGY. 2015. The Energy Challenge for Achieving the Millennium Development Goals. https://mirror.unhabitat.org/downloads/ docs/920_88725_The\%20Energy\%20challenge \%20for\%20achieving $\% 20$ the $\% 20$ millenium\%20development\%20goals.pdf

[11] NAZIO BATUAK. 2012. «A/RES/66/288. The future we want. Resolution adopted by the General» https://www.un.org/ga/search/view_doc. asp?symbol=A/RES/66/288\&Lang=E

[12] MORAN, M. 2020. «Energía», Desarrollo Sostenible. https://www.un.org/ sustainabledevelopment/es/energy/ (kontsulta eguna Sep. 10, 2020).

[13] BARBIER E. B. eta URGESS, J.C. 2019. «Sustainable development goal indicators: Analyzing trade-offs and complementarities». World Development, 122, 295-305, doi: 10.1016/j.worlddev.2019.05.026.

[14] MIOLA, A. eta SCHILTZ, F. 2019. «Measuring sustainable development goals performance: How to monitor policy action in the 2030 Agenda implementation?». Ecological Economics, 164, 106373, doi: 10.1016/j. ecolecon.2019.106373. 
[15] NAZIO BATUEN ESTATISTIKA ATALA. 2020. «SDG indicators. United Nations Global SDG Database». https://unstats.un.org/sdgs/indicators/database/

[16] Nazio Batuen Estatistika Atala. 2020. Tier Classification for Global SDG Indicators. IAEG-SDGs. https://unstats.un.org/sdgs/iaeg-sdgs/tierclassification/\#: :text=As\%20of\%2017\%20July\%202020\%3A\%20The $\% 20$ updated $\% 20$ tier $\% 20$ classification $\% 20$ contains, are $\% 20$ classified $\% 20$ into\%20different\%20tiers

[17] SWAIN, R. B. eta KARIMU, A. 2020. «Renewable electricity and sustainable development goals in the EU». World Development, 125, 104693, doi: 10.1016/j.worlddev.2019.104693.

[18] MARTÍNEZ, I. 2020. «La Agenda 2030: de la retórica a la práctica política». Galde, 28. https://www.galde.eu/eu/de-la-retorica-a-practica-politica/

[19] GEELS, F. W. 2020. «Micro-foundations of the multi-level perspective on socio-technical transitions: Developing a multi-dimensional model of agency through crossovers between social constructivism, evolutionary economics and neo-institutional theory». Technological Forecasting and Social Change, 152, 119894, doi: 10.1016/j.techfore.2019.119894.

[20] GEELS, F. W. 2004. «From sectoral systems of innovation to socio-technical systems: Insights about dynamics and change from sociology and institutional theory». Research Policy, 33, 6. zk., 897-920, doi: 10.1016/j. respol.2004.01.015.

[21] GEELS, F. W. 2019. «Socio-technical transitions to sustainability: a review of criticisms and elaborations of the Multi-Level Perspective». $\mathrm{Cu}$ rrent Opinion in Environmental Sustainability, 39, 87-201, doi: 10.1016/j. cosust.2019.06.009.

[22] GEELS F. W. eta SCHOT, J. 2007. «Typology of sociotechnical transition pathways». Res. Policy, 36, 3. zk., 399-417, doi: 10.1016/j. respol.2007.01.003.

[23] SCIENCE DIRECT. «ScienceDirect.com I Science, health and medical journals, full text articles and books». https://www.sciencedirect.com/ (kontsulta eguna 2021/10/07).

[24] UN. 2020. «Towards Achieving the Sustainable Development Goals in the UNECE Region». https://www.unece.org/index.php?id=53936 (kontsulta eguna 2021/10/07).

[25] UNECE. 2010. «Towards achieving the Sustainable Development Goals in the UNECE region A statistical portrait of progress and challenges» http:// www.unece.org/fileadmin/DAM/stats/publications/2020/SDG_report_for_ web.pdf (kontsulta eguna 2021/10/07).

[26] ESPAINIAKO GOBERNUA. 2016. «Agenda 2030. Objetivo 7. Energía asequible y no contaminante. Ministerio de derechos sociales y agenda 2030. Vicepresidencia segunda del gobierno». https:/www.agenda2030.gob.es/objetivos/objetivo7.htm\#datos (kontsulta eguna 2021/10/07). 
[27] EUSKO JAURLARITZA. 2019. «Euskal Ekarpena Garapen Jasangarrirako 2030 Agenda». https://www.euskadi.eus/agenda-2030/ (kontsulta eguna 2021/09/10).

[28] EUSKO JAURLARITZA. 2016. «Euskal Autonomia Erkidegoko herri-administrazioen energia-iraunkortasunari buruzko Lege Proiektua (Gobernu Bilera 2016-07-19)» https://www.irekia.euskadi.eus/eu/news/34006-gobierno-vasco-aprueba-proyecto-ley-sostenibilidad-energetica-las-administraciones-publicas-vascas-consejo-gobierno-2016 (kontsulta eguna 2021/09/10).

[29] EUSKO JAURLARITZA. 2018. «Alianza Alavesa por el Desarrollo Sostenible» https://www .irekia.euskadi.eus/es/news/48557-las-sailburus-artolazabal-beltran-heredia-san-jose-constitucion-alianza-alavesa-por-desarrollo-sostenible (kontsulta eguna 2021/09/24).

[30] GFA. 2018. «AGENDA 2030 ETA GARAPEN JASANGARRIKO HELBURUAK. Aurrerabide eta adierazleak Gipuzkoan. 2017ko GJHen jarraipen txostena (15. or.)» https://www .gipuzkoa.eus/eu/web/ingurumena/ta21/helburuak (kontsulta eguna 2021/09/24).

[31] MARTÍNEZ OSÉS, P. 2017. «Transformar Nuestro Mundo, ¿realidad o ficción? Chapter: Hacer realidad la Agenda: medios de implementación, revisión y seguimiento». UNESCO Etxea - Centro UNESCO del País Vasco. http://www.unescoetxea.org/dokumentuak/transformar_nuestro_mundo.pdf (kontsulta eguna 2021/09/24).

[32] THE WORLD BANK. 2019. «2019 Tracking SDG 7. The energy Progress Report»https://trackingsdg7.esmap.org/data/files/downloaddocuments/2019-Tracking\%20SDG7-Full\%20Report.pdf

[33] THE WORLD BANK, «2020 Tracking SDG 7. The energy Progress Report». 2020. https://trackingsdg7.esmap.org/data/files/downloaddocuments/01-sdg7-executivesummary_0.pdf (kontsulta eguna 2021/09/24)

[34] FEEM. 2020. «Population Without Electricity (FEEM). SDG 7. 2015-2019» https://sdsn.maps.arcgis.com/home/item.html?id=467115d863084c4f88d1fc 91f460a5b9

[35] SÀNCHEZ DE MADARIAGA, I., GARCÍA LÓPEZ, J. eta SISTO, R. 2018 «MIRANDO HACIA EL FUTURO: CIUDADES SOSTENIBLES. Los Objetivos de Desarrollo Sostenible en 100 ciudades españolas». REDS - Red Española para el Desarrollo Sostenible. https://reds-sdsn.es/wp-content/ uploads/2018/10/Informe-ODS-en-100-ciudades-2018-I-Resumen-web.pdf (kontsulta eguna 2021/09/24).

[36] IHOBE, EUSKO JAURLARITZA. 2019. «Tokiko 2030 Agenda. Nola heldu Garapen Jasangarriaren Helburuei tokiko eremutik.Gida praktikoa». https:// www.ihobe.eus/argitalpenak/tokiko-2030-agenda-nola-heldu-garapen-jasangarriaren-helburuei-tokiko-eremutik-gida-praktikoa (kontsulta eguna 2021/09/24).

[37] EUROSTAT. 2020. «SUSTAINABLE DEVELOPMENT INDICATORS. SDG 7 “AFFORDABLE AND CLEAN ENERGY”», https://ec.europa.eu/ eurostat/web/sdi/affordable-and-clean-energy (kontsulta eguna 2021/09/24). 
[38] EUSTAT. 2020. «Energia berriztagarrien kuota energiaren azken kontsumo gordinean, herrialdeka. 2004-2018». https://eu.eustat.eus/elementos/ ele0017100/Energia_berriztagarrien_kuota_energiaren_azken_kontsumo_ gordinean/tbl0017189_e.html (kontsulta eguna 2021/09/24).

[39] SÁNCHEZ DE MADARIAGA, I., GARCÍA LÓPEZ, J. eta Sisto, R. 2018 «Los Objetivos de Desarrollo Sostenible en 100 ciudades españolas. Madrid: Red Española para el Desarrollo Sostenible (REDS)». https://reds-sdsn.es/ wp-content/uploads/2018/10/Informe-ODS-en-100-ciudades-2018-I-Resumen-web.pdf (kontsulta eguna 2021/09/24).

[40] GUTIÉRREZ GOIRIA, J. 2020 «La Agenda 2030 en Euskadi: ¿compromiso o apariencia?», Galde, 28. https://www.galde.eu/es/la-agenda-2030-en-euskadi-compromiso-o-apariencia/

[41] TELLERÍA, J. 2020. «2030 Agendaren hizki txikia», Galde, 28. https:// www.galde.eu/eu/2030-agendaren-hizki-txikia/ (kontsulta eguna 2021/09/24).

[42] HERRERA, A. eta ETXANO, I. 2020. «Agenda 2030, Objetivos de Desarrollo Sostenible (ODS) y las perspectivas de la Sostenibilidad». https:// www .galde.eu/es/agenda-2030-objetivos-de-desarrollo-sostenible-ods-y-lasperspectivas-de-la-sostenibilidad/ (kontsulta eguna 2021/09/24).

[43] AKIZU-GARDOKI, O., BUENO, G., WIEDMANN, T., LOPEZGUEDE, J.M., ARTO, I., HERNANDEZ, P. eta MORAN, D. 2018. «Decoupling between human development and energy consumption within footprint accounts», J. Clean. Prod., 202 lib., 1145-1157, doi: 10.1016/j. jclepro.2018.08.235.

[44] AKIZU-GARDOKI, O., WAKIYAMA, T., WIEDMANN, T., BUENO, G., ARTO, I., LENZEN M. eta LOPEZ-GUEDE, J.M. 2020. «Hidden Energy Flow indicator to reflect the outsourced energy requirements of countries», J. Clean . Prod., 123827, doi: 10.1016/j.jclepro.2020.123827. 